\title{
Review
}

\section{Neuroprotective role of ATP-sensitive potassium channels in cerebral ischemia}

\author{
Hong-shuo SUN ${ }^{1,2,3,4, *}$, Zhong-ping $\mathrm{FENG}^{2, *}$ \\ Departments of ${ }^{1}$ Surgery, ${ }^{2}$ Physiology, ${ }^{3}$ Pharmacology and ${ }^{4}$ Institute of Medical Science, Faculty of Medicine, University of Toronto, \\ Toronto, Ontario, Canada M5S 1 A8
}

\begin{abstract}
ATP-sensitive potassium ( $\mathrm{K}_{\text {ATP }}$ ) channels are weak, inward rectifiers that couple metabolic status to cell membrane electrical activity, thus modulating many cellular functions. An increase in the ADP/ATP ratio opens $\mathrm{K}_{\text {ATP }}$ channels, leading to membrane hyperpolarization. $\mathrm{K}_{\text {ATP }}$ channels are ubiquitously expressed in neurons located in different regions of the brain, including the hippocampus and cortex. Brief hypoxia triggers membrane hyperpolarization in these central neurons. In vivo animal studies confirmed that knocking out the Kir6.2 subunit of the $\mathrm{K}_{\text {ATP }}$ channels increases ischemic infarction, and overexpression of the Kir6.2 subunit reduces neuronal injury from ischemic insults. These findings provide the basis for a practical strategy whereby activation of endogenous $\mathrm{K}_{\text {ATP }}$ channels reduces cellular damage resulting from cerebral ischemic stroke. $\mathrm{K}_{\text {ATP }}$ channel modulators may prove to be clinically useful as part of a combination therapy for stroke management in the future.
\end{abstract}

Keywords: ATP-sensitive potassium channel $\left(\mathrm{K}_{\text {ATP }}\right)$; Kir6.2; SUR subunit; stroke; nociception; neuropathic pain; neuroprotection

Acta Pharmacologica Sinica (2013) 34: 24-32; doi: 10.1038/aps.2012.138; published online 5 Nov 2012

\section{Introduction}

Potassium $\left(\mathrm{K}^{+}\right)$channels are the most ubiquitously distributed ion channels and are found virtually in all types of cells ${ }^{[1,2]}$. Because $\mathrm{K}^{+}$ions have a negative equilibrium potential across the cell membrane, the opening of $\mathrm{K}^{+}$channels stabilizes the membrane potential by hyperpolarizing the cell closer to the $\mathrm{K}^{+}$equilibrium potential $\left(\mathrm{E}_{\mathrm{K}}\right)$. Thus, $\mathrm{K}^{+}$channels play a major role in setting the resting membrane potential and the duration of action potentials. These channels also play a role in repetitive firing frequency, thereby suppressing the excitability of a cell ${ }^{[1,2]}$. Selective $\mathrm{K}^{+}$permeability was originally described in nerve cells ${ }^{[3,4]}$. To date, more than 80 genes for $\mathrm{K}^{+}$channel subunits have been identified in mammalian cells, and multiple $\mathrm{K}^{+}$channel subtypes are expressed in a single cell to control its $\mathrm{K}^{+}$permeability ${ }^{[1,2]}$. Inwardly rectifying $\mathrm{K}^{+}$(Kir) channels conduct the inward rectifier current, thus hyperpolarizing the membrane potential ${ }^{[5]}$.

Adenosine triphosphate (ATP)-sensitive $\mathrm{K}^{+}\left(\mathrm{K}_{\mathrm{ATP}}\right)$ channels are members of the Kir superfamily and were originally described in the heart ${ }^{[6]}$. These channels were later identified in many other tissues, including the skeletal muscle ${ }^{[7]}$, smooth

\footnotetext{
* To whom correspondence should be addressed.

E-mail hss.sun@utoronto.ca (Hong-shuo SUN); zp.feng@utoronto.ca (Zhong-ping FENG)

Received 2012-04-19 Accepted 2012-08-26
}

muscle $^{[8]}$, brain ${ }^{[9-12]}$, pituitary gland ${ }^{[13,14]}$, kidney ${ }^{[15]}$, and in pancreatic beta cells ${ }^{[16-19]}$. $K_{\text {ATP }}$ channels conduct inward-rectifier potassium currents that are inhibited by intracellular ATP and couple the cellular metabolic status to the electrical activity of the cell membrane ${ }^{[6,16,20,21]}$. An increase in the ATP/ADP ratio closes $\mathrm{K}_{\mathrm{ATP}}$ channels (leading to depolarization), whereas a decrease in the ATP/ADP ratio opens $\mathrm{K}_{\mathrm{ATP}}$ channels (leading to hyperpolarization). Thus, $\mathrm{K}_{\mathrm{ATP}}$ channels modulate many of the cellular events and functions under physiological and pathophysiological conditions. Recently, it has been proposed that $\mathrm{K}_{\mathrm{ATP}}$ channels are one of the non-glutamate mechanisms for stroke ${ }^{[22,23]}$. Broad reviews of $K_{A T P}$ channels in the heart ${ }^{[21,24]}$ and pancreatic cells ${ }^{[20,21,25]}$ have been presented elsewhere. The specific role of $\mathrm{K}_{\mathrm{ATP}}$ channels in the neurovascular unit in stroke has also been recently reviewed ${ }^{[26]}$. This review focuses on neuronal $\mathrm{K}_{\mathrm{ATP}}$ channels and the neuroprotective role of $\mathrm{K}_{\mathrm{ATP}}$ channels in cerebral ischemia.

\section{General description of $\mathbf{K}_{\text {ATP }}$ channels}

$\mathrm{K}_{\text {ATP }}$ channels are heteromultimers of Kir6 and sulfonylurea receptor (SUR) subunits ${ }^{[27]}$ (Figure 1). They are activated by energy depletion and conduct a weak inwardly rectifying $\mathrm{K}^{+}$ current, thus playing important roles in the regulation of cellular function by linking cellular metabolism to the electrical activity of cell membranes ${ }^{[20,27-29]}$ (Figure 2). 


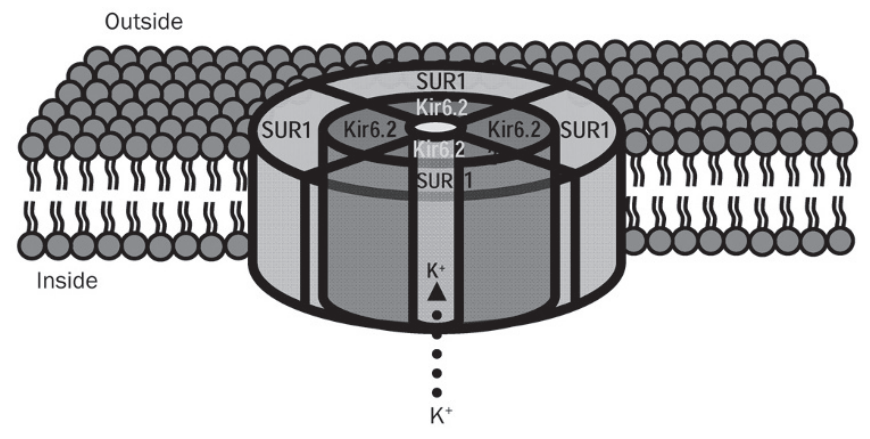

Figure 1. A schematic illustration showing the proposed structure of a $\mathrm{K}_{\text {ATP }}$ channel in neurons. The $\mathrm{K}_{\text {ATP }}$ channel is a hetero-octamer comprising two subunits: four pore-forming Kir6.2 subunits and four regulatory sulfonylurea receptor (SUR) subunits.

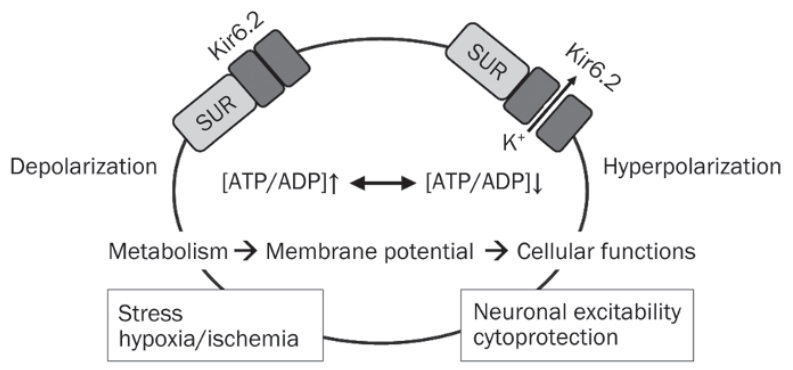

Figure 2. Schematic illustration of $K_{\text {ATP }}$ channels function in neurons. $\mathrm{K}_{\text {ATP }}$ channels serve as metabolic sensors to couple electrical activity of neurons. Under normal physiological conditions, $K_{\text {ATP }}$ channels remain closed due to the high ATP/ADP ratio. Reducing the ATP/ADP ratio by either decreasing ATP levels or enhancing ADP levels opens the channel and allows $\mathrm{K}^{+}$ions to exit the cells, thus hyperpolarizing the neurons. SUR, sulfonylurea receptor.

\section{$\mathrm{K}_{\text {ATP }}$ channel genes}

The Kir6 subfamily is a member of the weak inward rectifier family and has two members, Kir6.1 and Kir6.2. The Kir6.2 gene (KCNJ11) in humans is located on chromosome 11. Kir6.2 was cloned from a human genomic library and shares $96 \%$ amino acid identity with mouse and rat Kir6.2 ${ }^{[30]}$. Kir6.1 genes (KCNJ8) are mainly expressed in the mitochondria ${ }^{[12,31,32]}$. Two SUR subunits, SUR1 and SUR2, have been identified as the regulatory subunits of $\mathrm{K}_{\mathrm{ATP}}$ channels ${ }^{[33]}$. The SUR1 subunit is encoded by the ABCC8 gene, which is located on chromosome 11p15.1 and is mainly found in pancreatic beta cells and neurons ${ }^{[33-35]}$. The SUR2 subunit is encoded by the ABCC9 gene, which is located on chromosome 12p12.1 and is expressed mainly in the heart and skeletal muscles, as well as in some neurons ${ }^{[5,36]}$. SUR2 has two alternative splice variants, SUR2A and SUR2B, which have major differences in the last 42 C-terminal amino acid residues $(C 42)^{[37]}$. The C42 of SUR2B shows a higher homology to the C42 of SUR1 ${ }^{[37]}$.

\section{Structure of functional $\mathrm{K}_{\text {ATP }}$ channels}

$K_{\text {ATP }}$ channels are heteromultimers of the Kir6 and SUR sub- units. These subunits are in a 1:1 ratio of stoichiometry. The Kir6 subunit is the pore-forming subunit of $\mathrm{K}_{\text {ATP }}$ channels ${ }^{[30,38]}$. Kir6.2 mediates the inhibitory effect of ATP on the $K_{\text {ATP }}$ channels. The SUR subunits are members of the ATP-binding cassette $(A B C)$ protein superfamily ${ }^{[39]}$. The SUR subunits are sensitive to the adenine nucleotides, $\mathrm{Mg}-\mathrm{ADP}^{[20,27,29,40]}$. Reducing the intracellular concentration of ATP or the ATP/ADP ratio gates the $\mathrm{K}_{\mathrm{ATP}}$ channel.

A functional $K_{\text {ATP }}$ channel is assembled by four Kir6. $x$ and four SUR subunits, forming a hetero-octameric complex (SUR/Kir) $)_{4}$. The functional diversity of the $\mathrm{K}_{\mathrm{ATP}}$ channels results from the assembly of different subtypes of the Kir6.x and SUR subunits. Kir6.1 genes are mainly expressed in the mitochondria. Kir6.1-based channels have a smaller unitary conductance than Kir6.2 subtype channels ${ }^{[27]}$. Kir6.2 subunits are found in plasmalemmal membranes (cell surface membranes) $)^{[12,20,27,29,32]}$. Most functional $\mathrm{K}_{\mathrm{ATP}}$ channels contain the Kir6.2 subunit; thus, the heterogeneity observed between different $K_{\mathrm{ATP}}$ channels mainly arises from the differential expression of the SUR regulatory subunits. SUR1- and SUR2based channels are differentiated by their selective sensitivity to sulfonylureas drugs (such as glibenclamide), whereas SUR2A- and SUR2B-based channels are differentiated by their selective affinity to diazoxide ${ }^{[27]}$.

\section{Gating properties}

$\mathrm{K}_{\text {ATP }}$ channels exhibit fast and long interburst closing kinetics $^{[41-43]}$. The fast gating kinetics of the channels is determined by an intrinsic structure within the pore-loop that is near the selectivity filter of the Kir6.2 subunit $^{[41,44]}$. The long last interburst closing kinetics requires ATP binding to the TM2 helices $^{[42,45]}$. The conformational modeling describes one open and multiple closed states of the channel ${ }^{[36,43]}$. A current conducting channel requires all four Kir6.2 subunits in the open conformation, and ATP binding to any one of the four subunits will shift the channel to a closed state. SUR subunits are considered the gatekeepers of the ATP-inhibited Kir6.2 pores because they couple their N-terminal bundle of five transmembrane helices (TMD0-L0) to the outer helix and N-terminus of Kir6.2. This coupling bidirectionally modulates channel gating $^{[34,46]}$.

\section{Nucleotide sensitivities of $\mathrm{K}_{\text {ATP }}$ channels}

$\mathrm{K}_{\mathrm{ATP}}$ channels have distinctive sensitivities to the nucleotides ATP and ADP ${ }^{[27]}$. ATP binds to the cytoplasmic domain of the Kir6.2 subunit ${ }^{[44,47,48]}$ to inhibit the channel ${ }^{[49]}$. Each Kir6.2 subunit provides one ATP binding pocket, which is constituted by residues R50, I182, K185, R201, and G334 ${ }^{[5,36]}$. The interference of ATP binding releases channel inhibition and results in channel activation ${ }^{[5,36]}$. Mg-ADP is the endogenous activator of $K_{A T P}$ channels via the SUR regulatory subunits ${ }^{[5]}$. Each SUR subunit has two nucleotide binding domains (NBD1 and NBD2) and 17 putative transmembrane domains, including an N-terminal hydrophobic region (TMD0) containing five TM helices and two repeats of six TM helices (TMD1 and TMD2). The NBDs are found with the Walker A and Walker 
B motifs, which are located at the large cytosolic loops following the TMD1 and TMD2 repeats. Dimerization of the two NBDs generates the catalytic sites for ATP hydrolysis and thus is essential for transducing the effect of ADP to Kir6. $2^{[50-52]}$. Mutations that disrupt NBD dimerization reduce the ADPmediated activation of $\mathrm{K}_{\mathrm{ATP}}$ channels ${ }^{[49]}$. These mutations include G1479R ${ }^{[40,53]}$ in the NBD2 of SUR1 and V187D ${ }^{[54]}$ in the TMD0 of SUR1. Under normal physiological ATP levels, the probability that there will be open $\mathrm{K}_{\mathrm{ATP}}$ channels is less than $0.1 \%$ if SUR regulatory subunits are absent ${ }^{[5,36]}$.

\section{Pharmacology}

SUR subunits are major pharmacological targets. $\mathrm{K}_{\mathrm{ATP}}$ channels have distinctive pharmacology ${ }^{[27]}$. Sulfonylureas are a type of potassium channel blocker that works by binding to SUR subunits ${ }^{[27,55]}$. The most common sulfonylureas include glibenclamide, acetohexamide, tolbutamide, glipizide, and glimepiride. A single serine residue (S1237) located at the C-terminus of the TMs of the SUR1 subunit is critical for the high affinity binding $(\mathrm{Ki}=2 \mu \mathrm{mol} / \mathrm{L})$ of tolbutamide and glibenclamide to Kir6.2/SUR1 $\mathrm{K}_{\text {ATP }}$ channels ${ }^{[56]}$. A bivalent structure in the glibenclamide binding site requires the cytoplasmic loop 3 (between TM5 and TM6) and cytoplasmic loop 8 (between TM15-TM16) regions of the SUR1 subunit ${ }^{[57]}$. The low affinity binding site $(\mathrm{Ki}=1.8 \mathrm{mmol} / \mathrm{L})$ for tolbutamide is located on Kir6. $2^{[58]}$.

$\mathrm{K}_{\mathrm{ATP}}$ channels can be activated by a group of drugs called potassium channel openers. These drugs include diazoxide, cromakalim, pinacidil, nicorandil and minoxidil sulfate. Diazoxide binds to SUR1 subunits and enhances $\mathrm{K}^{+}$efflux through the Kir6.2/SUR1 channels in pancreatic beta-cells, resulting in cell membrane hyperpolarization ${ }^{[59]}$. In contrast, the drugs pinacidil, nicorandil and cromakalim have a high sensitivity to Kir6.2/SUR1 channels, thus leading to stronger effects on the Kir6.2/SUR2A subunits of cardiac $\mathrm{K}_{\text {ATP }}$ channels ${ }^{\text {[24, }}$ ${ }^{60]}$. The binding site for cromakalim, pinacidil and nicorandil is located within the TM2 domain of SUR2. The nucleotides L1249 and T1253 in SUR2A and T1286 and M1290 in SUR2B are necessary and sufficient for the channel opener effects ${ }^{[61-63]}$. $\mathrm{K}_{\mathrm{ATP}}$ channels in smooth muscle respond to all of these drugs. Recently, several new $\mathrm{K}_{\text {ATP }}$ channel openers, such as iptakalim, have been developed. Iptakalim showed cytoprotective effects $^{[64]}$ via activating the SUR subunits ${ }^{[65]}$. However, it is unknown whether iptakalim acts by regulating Kir6.2- $\mathrm{K}_{\text {ATP }}$ and/or mitoK ${ }_{\text {ATP }}$ channels ${ }^{[66]}$.

\section{Cellular regulation of $\mathrm{K}_{\text {ATP }}$ channels}

$\mathrm{K}_{\text {ATP }}$ channel activity is regulated by phosphatidylinositol 4,5-biphosphate (PIP2) via interaction with the cytoplasmic domain that is close to the ATP binding site of Kir6.2 (including residues R54, R176, R177, and R206) ${ }^{[28,67,68]}$. PIP2 decreases the ATP sensitivity of the channels by preventing the channel from closing, thus stabilizing the open state. $K_{\text {ATP }}$ channel activity is also regulated by protein kinase A (PKA) in smooth muscle cells ${ }^{[69,70]}$ and cytoskeletal actin in the cardiac atrium $^{[71]}$. $\mathrm{K}_{\mathrm{ATP}}$ channel activity is suppressed by a SNARE protein, syntaxin $1 \mathrm{~A}$, via protein-protein interactions with the SUR subunits ${ }^{[72-75]}$. Syntaxin $1 \mathrm{~A}$ decreases the activity ${ }^{[76]}$ and the membrane expression level of $\mathrm{K}_{\mathrm{ATP}}$ channels ${ }^{[77]}$. Syntaxin 1A binding to the SUR1 subunit also attenuates the effect of $\mathrm{K}^{+}$ channel openers, such as diazoxide, NNC55-0462, P1075, and cromakalim $^{[78,79]}$.

\section{$K_{\text {ATP }}$ channels in the central nervous system}

$\mathrm{K}_{\text {ATP }}$ channels are extensively expressed in various regions of the mammalian brain ${ }^{[9,11,80]}$, including the substantia nigra $(\mathrm{SNr})^{[81,82]}$, neocortex ${ }^{[83]}$, hippocampus ${ }^{[84]}$, and hypothalamus ${ }^{[85,86]}$. They have been detected in many cell types, such as glial cells ${ }^{[84,87]}$ and neurons in the hippocampus ${ }^{[88]}$, dorsal vagus ${ }^{[89]}$, hypothalamus ${ }^{[85,86,90]}$, and $\mathrm{SNr}^{[91]}$. Single cell RT-PCR analysis showed that Kir6.2 mRNA is predominantly expressed in interneurons and pyramidal, granule and neuroglial cells of the hippocampus in the brains from young rats aged $10-13 \mathrm{~d}^{[84]}$. In the adult brain, Kir6. 2 subunits have been found in hippocampal ${ }^{[87,92]}$, cortical ${ }^{[93]}$, and hypothalamic neurons ${ }^{[94]}$, as well as in the $\mathrm{SNr}$ pars reticulata ${ }^{[95]}$. Immunohistochemical studies showed that Kir6.2 subunits are mainly located in the somata and dendrites of the central neurons ${ }^{[92,93,96]}$. Mitochondrial $\mathrm{K}_{\mathrm{ATP}}$ channels are also found in the rat brain, and the expression level of Kir6.1 (per milligram of mitochondrial protein) is six to seven times higher than that in the heart and liver ${ }^{[12]}$. Radioligand binding studies showed that regional expression of $K_{\text {ATP }}$ channels in the brain showed different affinities to sulfonylureas ${ }^{[97]}$.

\section{Function of neuronal $K_{\text {ATP }}$ channels}

$\mathrm{K}_{\mathrm{ATP}}$ channels in the hypothalamus play a critical role in glucose homeostasis by regulating the secretion of counter-regulatory hormones, including glucagon and catecholamines, via the autonomic nervous system ${ }^{[98]}$. However, the primary role of $\mathrm{K}_{\mathrm{ATP}}$ channels in many other central neurons is not glucosensing ${ }^{[84,90,99]}$. For instance, basal activity of $\mathrm{K}_{\mathrm{ATP}}$ channels can affect neuronal excitability in non-glucosensing neurons ${ }^{[100,101]}$. In the dentate granule neurons in the mouse hippocampus, $\mathrm{K}_{\mathrm{ATP}}$ channels are expressed with a high density ${ }^{[84,99]}$. The single channel conductance of $\mathrm{K}_{\mathrm{ATP}}$ channels is suppressed by strophanthidin, which is a blocker of the $\mathrm{Na}^{+}-\mathrm{K}^{+}$ATPase. Moderate action potential firing can evoke $\mathrm{K}_{\text {ATP }}$ channel opening via Na influx and ATP depletion. The ketone body R-beta-hydroxybutyrate can enhance neuronal electrical activity by opening $\mathrm{K}_{\mathrm{ATP}}$ channels ${ }^{[102]}$. Similarly, single channel recordings in brainstem inspiratory neurons show that bursts of single $\mathrm{K}_{\mathrm{ATP}}$ channel openings are in synchrony with the respiratory firing rhythm. The probability of open channels $\left(\mathrm{P}_{\text {open }}\right)$ is increased by approximately $60 \%$ after a strong burst of action potentials ${ }^{[103]}$. Blocking the $\mathrm{Na}^{+}-\mathrm{K}^{+}$ATPase reduces the increased $\mathrm{P}_{\text {open }}$ of $\mathrm{K}_{\mathrm{ATP}}$ channels. Thus, ATP consumption in response to $\mathrm{Na}^{+}$influx from action potentials regulates the opening of $\mathrm{K}_{\text {ATP }}$ channels under physiological conditions. 
$\mathrm{K}_{\text {ATP }}$ channels in dorsal root ganglia (DRG) neurons may involve nociception and neuropathic pain

$\mathrm{K}_{\mathrm{ATP}}$ channels are also expressed in DRG neurons ${ }^{[104,105]}$. The subunits Kir6.2, SUR1 and SUR2, but not Kir6.1, are identified in the DRG neurons using immunohistochemistry and electrophysiology ${ }^{[104,105]}$. The neuronal injury in axotomy decreases the $\mathrm{K}_{\mathrm{ATP}}$ channel current in the primary afferent neurons in the DRG, which is mediated by CaMKII ${ }^{[106]}$. The suppressed $\mathrm{K}_{\text {ATP }}$ channels in axotomized DRG neurons are still responsive to the $\mathrm{K}_{\mathrm{ATP}}$ channel blocker glibenclamide and opener diazoxide. In addition, $\mathrm{K}_{\mathrm{ATP}}$ channels are activated by CaMKII activators. The neuroprotective role of these CaMKII-dependent $\mathrm{K}_{\mathrm{ATP}}$ channels may inhibit excitotoxic cell injury. $\mathrm{K}_{\mathrm{ATP}}$-mediated neuroprotection may be suppressed in axotomy. Thus, opening of the DRG neuronal $\mathrm{K}_{\mathrm{ATP}}$ channels decreases neuronal excitability, inhibits neurotransmission and possibly suppresses hyperalgesia. The $\mathrm{K}_{\text {ATP }}$ channels in the DRG neurons are potential therapeutic targets for antihyperalgesia in neuropathic pain.

$\mathrm{K}_{\mathrm{ATP}}$ channels in the forebrain involving neuroprotection against seizure

Overexpression of SUR1 in the forebrain, including the cortex, hippocampus and striatum, results in resistance to kainic acid-induced seizures ${ }^{[107]}$. Mice that overexpress SUR1 exhibit normal brain anatomy and morphology, as well as normal locomotor and cognitive behaviors. The regional transgenic overexpression of the SUR1 subunit of $\mathrm{K}_{\mathrm{ATP}}$ channels in the forebrain protects mice against kainic acid-induced seizure and hippocampal neuronal cell death. This observation indicates that the neuronal $\mathrm{K}_{\mathrm{ATP}}$ channels are important mediators of neuroprotection in the brain and may have potential applications in protecting neurons against hyperexcitability and excitotoxicity during seizure and epileptic insults.

$\mathrm{K}_{\text {ATP }}$ channels in the substantia nigra region involving neuroprotection against hypoxia-induced seizures

The SNr plays a crucial role in the propagation of seizures ${ }^{[108]}$, which can be evoked by insults such as hypoxia and hypoglycemia. The $\mathrm{K}_{\mathrm{ATP}}$ channels expressed in the $\mathrm{SNr}$ region are composed of the Kir6.2/SUR1 subunits ${ }^{[109]}$, which display high affinity binding to sulfonylureas ${ }^{[97,110]}$. $\mathrm{K}_{\text {ATP }}$ channels are predominantly expressed in GABAergic neurons ${ }^{[11]}$. A decrease in glucose levels leads to the opening of presynaptic $\mathrm{K}_{\mathrm{ATP}}$ channels and suppression of GABA release ${ }^{[11]}$. $\mathrm{K}_{\text {ATP }}$ channels are involved in protecting the brain against seizures and mediating ischemic preconditioning in the brain ${ }^{[11]}$. A brief hypoxia (90 s) hyperpolarizes the membrane potential and decreases the firing rate by $30 \%$ in wild-type SNr neurons. In contrast, hypoxic conditions depolarize the membrane potential and increase the firing rate in the Kir6.2 $2^{-/-}$neurons, suggesting that the $\mathrm{K}_{\mathrm{ATP}}$ channel-mediated suppressive effect on $\mathrm{SNr}$ activity is sufficient to reverse hypoxia-induced superactivity of the neurons. In addition, neurons deficient for Kir6.2 show more susceptibility to hypoxic damage than their wild-type counterparts $^{[95]}$. The Kir6. $2^{-/-}$mice exhibit generalized seizures in response to the same period of hypoxia, whereas wild-type mice revive normally ${ }^{[95]}$. $\mathrm{K}_{\mathrm{ATP}}$ channels suppress the neuronal activity in the SNr. This suppression may determine the seizure threshold under hypoxic conditions ${ }^{[95]}$. SUR1 ${ }^{-/-}$mice also exhibit hypersensitivity to hypoxic insult ${ }^{[111]}$. Thus, the $\mathrm{K}_{\mathrm{ATP}}$ channels in SNr neurons act as a metabolic sensor to mediate hypoxic hyperpolarization, and in turn, prevent seizure propagation during hypoxic stress. This may have implications in human epilepsy ${ }^{[112,113]}$.

\section{$K_{\text {ATP }}$ channels and their neuroprotective role in cerebral ischemia}

Similar to that observed in cardiac ischemia ${ }^{[55,60,114]}$, a neuroprotective role of $\mathrm{K}_{\mathrm{ATP}}$ channels has also been suggested in focal and global ischemia models twenty years ago ${ }^{[15]}$. $\mathrm{K}_{\text {ATP }}$ channels in a large number of central neurons remain closed, except under conditions of severe metabolic deprivation, such as anoxia or ischemia (Figure 2).

Activation of mitochondrial $\mathrm{K}_{\text {ATP }}$ channels initiates ischemic pre-conditioning and prevents the mitochondrial dysfunction associated with $\mathrm{Ca}^{2+}$ overload during ischemic reperfusion in the heart ${ }^{[116-118]}$. In adult animals, application of mitochondrial $K_{\text {ATP }}$ openers, such as diazoxide or BMS-191095, reduces neuronal death (rats: ${ }^{[116,119-121]}$; mice: ${ }^{[122]}$ ), whereas a selective mitochondrial $\mathrm{K}_{\text {ATP }}$ channel blocker, 5-hydroxydecanoate, prevents preconditioning-induced neuronal protection in middle cerebral artery occlusion (MCAO) focal cerebral ischemia ${ }^{[123]}$. In contrast, xenon-induced preconditioning is not associated with the mitochondrial channels, but rather, is mediated by plasmalemma $\mathrm{K}_{\text {ATP }}$ channels ${ }^{[124]}$. The mechanisms underlying the mitochondrial $\mathrm{K}_{\mathrm{ATP}}$ channel-related neuroprotective effects remain unclear. However, SUR1 subunits may not be directly involved because adult SUR1 knockout mice exhibit preconditional ischemic tolerance ${ }^{[124]}$.

Activation of the plasmalemmal $\mathrm{K}_{\mathrm{ATP}}$ channels hyperpolarizes neurons (Figure 3) and may stabilize the resting membrane potential during ischemic insults and stress ${ }^{[125]}$, which, in turn, can protect neurons against neuronal damage and neurodegeneration that is caused by anoxic membrane depolarization and excitotoxicity ${ }^{[115,126]}$. Expression of $\mathrm{K}_{\mathrm{ATP}}$ channel

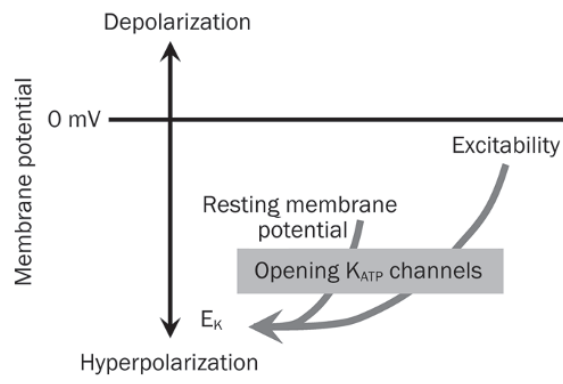

Figure 3. Opening of $\mathrm{K}_{\text {ATP }}$ channels lead to $\mathrm{K}^{+}$ion efflux and hyperpolarization of the cell membrane, resulting in a decrease in cell excitability. This hyperpolarization occurs by making the membrane potential more negative, which brings it towards the potassium equilibrium potential $\left(E_{k}\right)$. Hyperpolarization suppresses and inhibits cell excitability. 
genes and proteins have been detected by $\mathrm{PCR}^{[84]}$ and immunohistochemistry in different neuronal populations in the hippocampus of adult rats ${ }^{[87]}$. $\mathrm{K}_{\text {ATP }}$ channels are preferentially expressed in the interneurons, CA3 neurons, and granule cells that are resistant to ischemic injury, especially in global ischemia ${ }^{[127,128]}$. However, the underlying mechanism is not yet understood.

Under normal physiological conditions, neuronal $\mathrm{K}_{\mathrm{ATP}}$ channels are presumably closed due to high intracellular ATP levels (Figure 2). During the initial phase of hypoxia and ischemia, energy failure reduces the ATP/ADP ratio, which activates neuronal $\mathrm{K}_{\mathrm{ATP}}$ channels, causing hyperpolarization of the neuronal cell membrane and suppression of neuronal activity (Figure 2). Similar to previous reports ${ }^{[88,95,129,130]}$, we reported that membrane hyperpolarization was induced during the first $5 \mathrm{~min}$ of ischemia in both hippocampal and cortical neurons $^{[92,93]}$. Using Kir6.2 knockout mice, we further reported that hippocampal CA1 neurons that were deficient for Kir6.2 revealed rapid depolarization and increased neuronal activity in response to hypoxia. In contrast, neuronal suppression occurred in wild-type neurons under similar conditions ${ }^{[92]}$. Hypoxic hyperpolarization in wild-type hippocampal CA1 neurons could be prevented by the $\mathrm{K}_{\mathrm{ATP}}$ channel blocker tolbutamide. Depending on the length of the hypoxic challenge, wild-type neurons initially demonstrate hypoxic hyperpolarization, which is then followed by speedy recovery and stabilization of the cell membrane potential. Our in vivo study also showed that cortical neurons lacking the Kir6.2 gene are more vulnerable than wild-type neurons to ischemic insults by middle cerebral artery occlusion ${ }^{[93]}$. Our findings provide the first convincing evidence that Kir6.2 containing $\mathrm{K}_{\mathrm{ATP}}$ channels are important for neuroprotection against cerebral ischemia.

An independent group, using knock-in (KI) mice overexpressing Kir6.2-containing $\mathrm{K}_{\text {ATP }}$ channels, further confirmed the crucial role of Kir6.2 in neuroprotection against hypoxiaischemia ${ }^{[131]}$. Specifically, overexpression of Kir6.2 reduced the spontaneous electrical activity recorded in hippocampal and cortical neurons. In this study, the resting membrane potentials for both animals were not described. In response to hypoxia-ischemia challenge, the infarction in Kir6.2 overexpressing animals was smaller compared to that of the wildtype animals. The findings using overexpression of Kir6.2 in Kir6.2 KO mice strongly support the notion that Kir6.2 is neuroprotective against ischemia.

In addition to neurons, $\mathrm{K}_{\mathrm{ATP}}$ channels are also found in astrocytes and microglial cells. Recent studies show that the SUR1 receptor is upregulated in response to pro-inflammatory signals, and the $\mathrm{K}_{\text {ATP }}$ channel blocker, glibenclamide, exerts neuroprotective effects through its action on non-neuronal cells in the MCAO model in rat ${ }^{[132,133]}$. Because glibenclamide also has non- $\mathrm{K}_{\mathrm{ATP}}$ channel effects, mechanisms underlying the effect of glibenclamide remain to be further investigated.

\section{Summary and therapeutic aspects}

Kir6.2 of $\mathrm{K}_{\mathrm{ATP}}$ channels is ubiquitously expressed in the brain. Studies using Kir6.2 knock-in or knock-out mouse models indicate that the opening of $\mathrm{K}_{\mathrm{ATP}}$ channels shifts the cell membrane potential more negatively (hyperpolarization) towards the $\mathrm{E}_{\mathrm{K}}$, leading to suppression of neuronal activity and excitability. Thus, opening $\mathrm{K}_{\mathrm{ATP}}$ channels under metabolic stress can protect neurons against neuronal injury during cerebral ischemia and stroke. While the functional roles of Kir6.1, SUR1 and SUR2 in neuroprotection necessitate further evaluation, it has been suggested that $\mathrm{K}_{\text {ATP }}$ channels may be involved in the remodeling of neurovascular units in stroke ${ }^{[26]}$. Kir6.2containing $\mathrm{K}_{\text {ATP }}$ channels regulate the membrane potential and contribute to the pathophysiological hyperexcitability of neurons induced by hypoxia and ischemia incidents. Thus, Kir6.2-containing $\mathrm{K}_{\mathrm{ATP}}$ channels may have therapeutic potential as a target for stroke. It is anticipated that $\mathrm{K}_{\mathrm{ATP}}$ channel modulators will be useful in the treatment of stroke.

\section{Abbreviations}

$\mathrm{ABC}$, ATP-binding cassette protein; ABCC8, ATP-binding cassette $\mathrm{C} 8$ gene; CaMKII, calmodulin kinase II; DRG, dorsal root ganglia; $\mathrm{K}_{\mathrm{ATP}}$, ATP sensitive potassium channels; $\mathrm{KCN}$, gene name for potassium channel; KCNJ11, potassium channel J11 gene; Kir, inward rectifier potassium channels; MCAO, iddle cerebral artery occlusion; NBD, nucleotide binding domain; PIP2, phosphatidylinositol 4,5-biphosphatel; RT-PCR, reverse transcription polymerase chain reaction; $\mathrm{SNr}$, substantia nigra; SUR, sulfonylurea receptor; TM, transmembrane region; TMD, transmembrane domain.

\section{Acknowledgements}

This work was supported by a Grant-In-Aid operating grant from the Heart and Stroke Foundation of Canada to HSS. ZPF holds a New Investigator Award from the Heart and Stroke Foundation of Canada.

\section{References}

1 Miller C. An overview of the potassium channel family. Genome Biol 2000; 1: REVIEWS0004.

2 B Hille. Potassium Channels and Chloride Channels in Ion channels of excitable membranes. 3ed. Sinauer Associates, Inc, Sunderkabd, Massachusetts USA, 2001. p 131-68.

3 Hodgkin AL, Huxley AF. Potassium leakage from an active nerve fibre. Nature 1946; 158: 376.

4 Hodgkin AL, Huxley AF. Currents carried by sodium and potassium ions through the membrane of the giant axon of Loligo. J Physiol 1952; 116: 449-72.

5 Hibino H, Inanobe A, Furutani K, Murakami S, Findlay I, Kurachi Y. Inwardly rectifying potassium channels: their structure, function, and physiological roles. Physiol Rev 2010; 90: 291-366.

6 Noma A. ATP-regulated $\mathrm{K}^{+}$channels in cardiac muscle. Nature 1983; 305: 147-8.

7 Spruce AE, Standen NB, Stanfield PR. Voltage-dependent ATPsensitive potassium channels of skeletal muscle membrane. Nature 1985; 316: 736-8.

8 Standen NB, Quayle JM, Davies NW, Brayden JE, Huang Y, Nelson MT. Hyperpolarizing vasodilators activate ATP-sensitive $\mathrm{K}^{+}$channels in arterial smooth muscle. Science 1989; 245: 177-80.

9 Ashford ML, Sturgess NC, Trout NJ, Gardner NJ, Hales CN. Adenosine- 
5 '-triphosphate-sensitive ion channels in neonatal rat cultured central neurones. 1988; 412: 297-304.

10 Bernardi H, Fosset M, Lazdunski M. Characterization, purification, and affinity labeling of the brain $\left[{ }^{3} \mathrm{H}\right]$ glibenclamide-binding protein, a putative neuronal ATP-regulated $\mathrm{K}^{+}$channel. Proc Natl Acad Sci U S A 1988; 85: 9816-20.

11 Amoroso S, Schmid-Antomarchi H, Fosset M, Lazdunski M. Glucose, sulfonylureas, and neurotransmitter release: role of ATP-sensitive $\mathrm{K}^{+}$ channels. Science 1990; 247: 852-4.

12 Bajgar R, Seetharaman S, Kowaltowski AJ, Garlid KD, Paucek P. Identification and properties of a novel intracellular (mitochondrial) ATP-sensitive potassium channel in brain. J Biol Chem 2001; 276: 33369-74.

13 Bernardi H, De W Jr, Epelbaum J, Mourre C, Amoroso S, Slama A, et al. ATP-modulated $\mathrm{K}^{+}$channels sensitive to antidiabetic sulfonylureas are present in adenohypophysis and are involved in growth hormone release. Proc Natl Acad Sci U S A 1993; 90: 1340-4.

14 Inagaki N, Tsuura Y, Namba N, Masuda K, Gonoi T, Horie M, et al. Cloning and functional characterization of a novel ATP-sensitive potassium channel ubiquitously expressed in rat tissues, including pancreatic islets, pituitary, skeletal muscle, and heart. J Biol Chem 1995; 270: 5691-4.

15 Hunter M, Giebisch G. Calcium-activated K-channels of Amphiuma early distal tubule: inhibition by ATP. Pflugers Arch 1988; 412: 331-3.

16 Ashcroft FM, Harrison DE, Ashcroft SJ. Glucose induces closure of single potassium channels in isolated rat pancreatic beta-cells. Nature 1984; 312: 446-8.

17 Cook DL, Hales CN. Intracellular ATP directly blocks $\mathrm{K}^{+}$channels in pancreatic B-cells. Nature 1984; 311: 271-3.

18 Rorsman P, Trube G. Glucose dependent $\mathrm{K}^{+}$-channels in pancreatic beta-cells are regulated by intracellular ATP. Pflugers Arch 1985; 405: 305-9.

19 Kakei M, Kelly RP, Ashcroft SJ, Ashcroft FM. The ATP-sensitivity of $\mathrm{K}^{+}$ channels in rat pancreatic B-cells is modulated by ADP. FEBS Lett 1986; 208: 63-6.

20 Seino S. ATP-sensitive potassium channels: a model of heteromultimeric potassium channel/receptor assemblies. Annu Rev Physiol 1999; 61: 337-62.

21 Seino S. Miki T. Physiological and pathophysiological roles of ATPsensitive $\mathrm{K}^{+}$channels. Prog. Biophys. Mol Biol 2003; 81: 133-76.

22 Besancon E, Guo S, Lok J, Tymianski M, Lo EH. Beyond NMDA and AMPA glutamate receptors: emerging mechanisms for ionic imbalance and cell death in stroke. Trends Pharmacol. Sci 2008; 29: 268-75.

23 Tymianski M. Emerging mechanisms of disrupted cellular signaling in brain ischemia. Nat Neurosci 2011; 14: 1369-73.

24 Isomoto S, Kurachi Y. Function, regulation, pharmacology, and molecular structure of ATP-sensitive $\mathrm{K}^{+}$channels in the cardiovascular system. J Cardiovasc Electrophysiol 1997; 8: 1431-46.

25 Huopio H, Shyng SL, Otonkoski T, Nichols CG. $K_{\text {ATP }}$ channels and insulin secretion disorders. Am J Physiol Endocrinol Metab 2002; 283: E207-16.

26 Sun XL, Hu G. ATP-sensitive potassium channels: a promising target for protecting neurovascular unit function in stroke. Clin Exp Pharmacol Physiol 2010; 37: 243-52.

27 Babenko AP, guilar-Bryan L, Bryan J. A view of sur/KIR6.X, $\mathrm{K}_{\text {ATP }}$ channels. Annu Rev Physiol 1998; 60: 667-87.

28 Baukrowitz T, Schulte U, Oliver D, Herlitze S, Krauter T, Tucker SJ, et al. PIP2 and PIP as determinants for ATP inhibition of $\mathrm{K}_{\text {ATP }}$ channels. Science 1998; 282: 1141-4.
29 Miki T, Nagashima K, Seino S. The structure and function of the ATPsensitive $\mathrm{K}^{+}$channel in insulin-secreting pancreatic beta-cells. J Mol Endocrinol 1999; 22: 113-23.

30 Inagaki N, Gonoi T, Clement JP, Namba N, Inazawa J, Gonzalez G, et al. Reconstitution of IK ATP: an inward rectifier subunit plus the sulfonylurea receptor. Science 1995; 270: 1166-70.

31 Inoue I, Nagase H, Kishi K, Higuti T. ATP-sensitive $\mathrm{K}^{+}$channel in the mitochondrial inner membrane. Nature 1991; 352: 244-7.

32 Garlid KD. Opening mitochondrial $\mathrm{K}_{\text {ATP }}$ in the heart - what happens, and what does not happen. Basic Res Cardiol 2000; 95: 275-9.

33 Aguilar-Bryan L, Nichols CG, Wechsler SW, Clement JP, Boyd AE III, Gonzalez G, et al. Cloning of the beta cell high-affinity sulfonylurea receptor: a regulator of insulin secretion. Science 1995; 268 : 423-6.

34 Babenko AP, Bryan J. Sur domains that associate with and gate $\mathrm{K}_{\text {ATP }}$ pores define a novel gatekeeper. J Biol Chem 2003; 278: 41577-80.

35 Inagaki N, Gonoi T, Clement JP, Wang CZ, Aguilar-Bryan L, Bryan J, et al. A family of sulfonylurea receptors determines the pharmacological properties of ATP-sensitive $\mathrm{K}^{+}$channels. Neuron 1996; 16 : 1011-7.

36 Nichols CG. KATP channels as molecular sensors of cellular metabolism. Nature 2006; 440: 470-6.

37 Isomoto S, Kondo C, Yamada M, Matsumoto S, Higashiguchi O, Horio Y, et al. A novel sulfonylurea receptor forms with BIR (Kir6.2) a smooth muscle type ATP-sensitive $\mathrm{K}^{+}$channel. J Biol Chem 1996; 271 : 24321-4.

38 Ammala C, Moorhouse A, Gribble F, Ashfield R, Proks P, Smith PA, et al. Promiscuous coupling between the sulphonylurea receptor and inwardly rectifying potassium channels. Nature 1996; 379: 545-8.

39 Higgins CF. ABC transporters: from microorganisms to man. Annu Rev Cell Biol 1992; 8: 67-113.

40 Nichols CG, Shyng SL, Nestorowicz A, Glaser B, Clement JP, Gonzalez $\mathrm{G}$, et al. Adenosine diphosphate as an intracellular regulator of insulin secretion. Science 1996; 272: 1785-7.

41 Proks P, Capener CE, Jones P, Ashcroft FM. Mutations within the Ploop of Kir6.2 modulate the intraburst kinetics of the ATP-sensitive potassium channel. J Gen Physiol 2001; 118: 341-53.

42 Jiang Y, Lee A, Chen J, Cadene M, Chait BT, MacKinnon R. The open pore conformation of potassium channels. Nature 2002; 417: 523-6.

43 Enkvetchakul D, Nichols CG. Gating mechanism of $\mathrm{K}_{\text {ATP }}$ channels: function fits form. J Gen Physiol 2003; 122: 471-80.

44 Drain P, Li L, Wang J. KATP channel inhibition by ATP requires distinct functional domains of the cytoplasmic $C$ terminus of the pore-forming subunit. Proc Natl Acad Sci U S A 1998; 95: 13953-8.

45 Drain P, Geng X, Li L. Concerted gating mechanism underlying $\mathrm{K}_{\text {ATP }}$ channel inhibition by ATP. Biophys J 2004; 86: 2101-12.

46 Babenko AP, Bryan J. SUR-dependent modulation of $\mathrm{K}_{\text {ATP }}$ channels by an N-terminal KIR6.2 peptide. Defining intersubunit gating interactions. J Biol Chem 2002; 277: 43997-4004.

47 Antcliff JF, Haider S, Proks P, Sansom MS, Ashcroft FM. Functional analysis of a structural model of the ATP-binding site of the $\mathrm{K}_{\text {ATP }}$ channel Kir6.2 subunit. EMBO J 2005; 24: 229-39.

48 Dong K, Tang LQ, MacGregor GG, Leng Q, Hebert SC. Novel nucleotide-binding sites in ATP-sensitive potassium channels formed at gating interfaces. EMBO J 2005; 24: 1318-29.

49 Yamada $\mathrm{M}$, Kurachi $\mathrm{Y}$. The nucleotide-binding domains of sulfonylurea receptor $2 \mathrm{~A}$ and $2 \mathrm{~B}$ play different functional roles in nicorandilinduced activation of ATP-sensitive $\mathrm{K}^{+}$channels. Mol Pharmacol 2004; 65: 1198-207.

50 Campbell JD, Proks P, Lippiat JD, Sansom MS, Ashcroft FM. Identifi- 
cation of a functionally important negatively charged residue within the second catalytic site of the SUR1 nucleotide-binding domains. Diabetes 2004; 53: S123-7.

51 Masia R, Nichols CG. Functional clustering of mutations in the dimer interface of the nucleotide binding folds of the sulfonylurea receptor. J Biol Chem 2008; 283: 30322-9.

52 Vergani P, Lockless SW, Nairn AC, Gadsby DC. CFTR channel opening by ATP-driven tight dimerization of its nucleotide-binding domains. Nature 2005; 433: 876-80.

53 Sharma N, Crane A, Gonzalez G, Bryan J, Aguilar-Bryan L. Familial hyperinsulinism and pancreatic beta-cell ATP-sensitive potassium channels. Kidney Int 2000; 57: 803-8.

54 Otonkoski T, Ammala C, Huopio H, Cote GJ, Chapman J, Cosgrove K, et al. A point mutation inactivating the sulfonylurea receptor causes the severe form of persistent hyperinsulinemic hypoglycemia of infancy in Finland. Diabetes 1999; 48: 408-15.

55 Misler S, Giebisch G. ATP-sensitive potassium channels in physiology, pathophysiology, and pharmacology. Curr Opin Nephrol Hypertens 1992; 1: 21-33.

56 Ashfield R, Gribble FM, Ashcroft SJ, Ashcroft FM. Identification of the high-affinity tolbutamide site on the SUR1 subunit of the $\mathrm{K}_{\text {ATP }}$ channel. Diabetes 1999; 48: 1341-7.

57 Mikhailov MV, Mikhailova EA, Ashcroft SJ. Molecular structure of the glibenclamide binding site of the beta-cell $\mathrm{K}_{\text {ATP }}$ channel. FEBS Lett 2001; 499: 154-60.

58 Gribble FM, Tucker SJ, Ashcroft FM. The interaction of nucleotides with the tolbutamide block of cloned ATP-sensitive $\mathrm{K}^{+}$channel currents expressed in Xenopus oocytes: a reinterpretation. J Physiol 1997; 504: 35-45.

59 Ashcroft FM, Gribble FM. New windows on the mechanism of action of $\mathrm{K}_{\text {ATP }}$ channel openers. Trends Pharmacol Sci 2000; 21: 439-45.

60 Terzic A, Jahangir A, Kurachi Y. Cardiac ATP-sensitive $\mathrm{K}^{+}$channels: regulation by intracellular nucleotides and $\mathrm{K}^{+}$channel-opening drugs. Am J Physiol 1995; 269: C525-45.

61 Moreau C, Jacquet H, Prost AL, D'hahan N, Vivaudou M. The molecular basis of the specificity of action of $\mathrm{K}_{\text {ATP }}$ channel openers. EMBO J 2000; 19: 6644-51.

62 Moreau C, Gally F, Jacquet-Bouix H, Vivaudou M. The size of a single residue of the sulfonylurea receptor dictates the effectiveness of $\mathrm{K}_{\text {ATP }}$ channel openers. Mol Pharmacol 2005; 67: 1026-33.

63 Moreau C, Prost AL, Derand R, Vivaudou M. SUR, ABC proteins targeted by $\mathrm{K}_{\text {ATP }}$ channel openers. J Mol Cell Cardiol 2005; 38: 951-63.

64 Wang $\mathrm{H}$, Zhang YL, Tang XC, Feng HS, Hu G. Targeting ischemic stroke with a novel opener of ATP-sensitive potassium channels in the brain. Mol Pharmacol 2004; 66: 1160-8.

65 Hu LF, Wang S, Shi XR, Yao HH, Sun YH, Ding JH, et al. G ATPsensitive potassium channel opener iptakalim protected against the cytotoxicity of $\mathrm{MPP}^{+}$on SH-SY5Y cells by decreasing extracellular glutamate level. J Neurochem 2005; 94: 1570-9.

66 Costa AD. Iptakalim: a new or just another KCO? Cardiovasc Res 2009; 83: 417-8.

67 Shyng SL, Cukras CA, Harwood J, Nichols CG. Structural determinants of PIP(2) regulation of inward rectifier $\mathrm{K}_{\text {ATP }}$ channels. J Gen Physiol 2000; 116: 599-608.

68 Shyng SL, Barbieri A, Gumusboga A, Cukras C, Pike L, Davis JN, et al. Modulation of nucleotide sensitivity of ATP-sensitive potassium channels by phosphatidylinositol-4-phosphate 5-kinase. Proc Natl Acad Sci U S A 2000; 97: 937-41.

69 Quinn KV, Giblin JP, Tinker A. Multisite phosphorylation mechanism for protein kinase A activation of the smooth muscle ATP-sensitive $\mathrm{K}^{+}$ channel. Circ Res 2004; 94: 1359-66.
70 Shi Y, Wu Z, Cui N, Shi W, Yang Y, Zhang X, et al. PKA phosphorylation of SUR2B subunit underscores vascular $K_{A T P}$ channel activation by beta-adrenergic receptors. Am J Physiol Regul Integr Comp Physiol 2007; 293: R1205-14.

71 Van Wagoner DR. Mechanosensitive gating of atrial ATP-sensitive potassium channels. Circ Res 1993; 72: 973-83.

72 Kang Y, Leung YM, Manning-Fox JE, Xia F, Xie H, Sheu L, et al. Syntaxin- $1 \mathrm{~A}$ inhibits cardiac $\mathrm{K}_{\text {ATP }}$ channels by its actions on nucleotide binding folds 1 and 2 of sulfonylurea receptor 2A. J Biol Chem 2004; 279: 47125-31.

73 Pasyk EA, Kang Y, Huang X, Cui N, Sheu L, Gaisano HY. Syntaxin$1 \mathrm{~A}$ binds the nucleotide-binding folds of sulphonylurea receptor 1 to regulate the $\mathrm{K}_{\text {ATP }}$ channel. J Biol Chem 2004; 279: 4234-40.

74 Chao C, Liang T, Kang Y, Lin X, Xie H, Feng ZP, et al. Syntaxin-1A inhibits $K_{\text {ATP }}$ channels by interacting with specific conserved motifs within sulfonylurea receptor 2A. J Mol Cell Cardiol 2011; 51: 790802.

75 Chang N, Liang T, Lin X, Kang Y, Xie H, Feng ZP, et al. Syntaxin-1A interacts with distinct domains within nucleotide-binding folds of sulfonylurea receptor 1 to inhibit beta-cell ATP-sensitive potassium channels. J Biol Chem 2011; 286: 23308-18.

76 Cui N, Kang Y, He Y, Leung YM, Xie H, Pasyk EA, et al. H3 domain of syntaxin $1 \mathrm{~A}$ inhibits $\mathrm{K}_{\text {ATP }}$ channels by its actions on the sulfonylurea receptor 1 nucleotide-binding folds-1 and -2. J Biol Chem 2004; 279 : 53259-65.

77 Chen PC, Bruederle CE, Gaisano HY, Shyng SL. Syntaxin 1A regulates surface expression of \{beta\}-cell ATP-sensitive potassium channels. Am J Physiol Cell Physiol 2011; 300: C506-16.

$78 \mathrm{Ng} \mathrm{B}$, Kang Y, Elias CL, He Y, Xie H, Hansen JB, et al. The actions of a novel potent islet beta-cell specific ATP-sensitive $\mathrm{K}^{+}$channel opener can be modulated by syntaxin-1A acting on sulfonylurea receptor 1 . Diabetes 2007; 56: 2124-34.

79 Ng B, Kang Y, Xie H, Sun H, Gaisano HY. Syntaxin-1A inhibition of P-1075, cromakalim, and diazoxide actions on mouse cardiac ATPsensitive potassium channel. Cardiovasc Res 2008; 80: 365-74.

80 Bernardi H, Fosset M, Lazdunski M. ATP/ADP binding sites are present in the sulfonylurea binding protein associated with brain ATPsensitive $\mathrm{K}^{+}$channels. Biochemistry 1992; 31: 6328-32.

81 Roper J, Ashcroft FM. Metabolic inhibition and low internal ATP activate $\mathrm{K}_{\text {ATP }}$ channels in rat dopaminergic substantia nigra neurones. Pflugers Arch 1995; 430: 44-54.

82 Stanford IM, Lacey MG. Electrophysiological investigation of adenosine trisphosphate-sensitive potassium channels in the rat substantia nigra pars reticulata. Neuroscience 1996; 74: 499-509.

83 Ohno-Shosaku T, Yamamoto C. Identification of an ATP-sensitive $\mathrm{K}^{+}$ channel in rat cultured cortical neurons. Pflugers Arch 1992; 422: 260-6.

84 Zawar C, Plant TD, Schirra C, Konnerth A, Neumcke B. Cell-type specific expression of ATP-sensitive potassium channels in the rat hippocampus. J Physiol 1999; 514: 327-41.

85 Ashford ML, Boden PR, Treherne JM. Tolbutamide excites rat glucoreceptive ventromedial hypothalamic neurones by indirect inhibition of ATP-K ${ }^{+}$channels. Br J Pharmacol 1990; 101: 531-40.

86 Ashford ML, Boden PR, Treherne JM. Glucose-induced excitation of hypothalamic neurones is mediated by ATP-sensitive $\mathrm{K}^{+}$channels. Pflugers Arch 1990; 415: 479-83.

87 Zhou M, Tanaka O, Suzuki M, Sekiguchi M, Takata K, Kawahara K, et al. Localization of pore-forming subunit of the ATP-sensitive $\mathrm{K}(+)$ channel, Kir6.2, in rat brain neurons and glial cells. Brain Res Mol Brain Res 2002; 101: 23-32.

88 Fujimura N, Tanaka E, Yamamoto S, Shigemori M, Higashi H. Contri- 
bution of ATP-sensitive potassium channels to hypoxic hyperpolarization in rat hippocampal CA1 neurons in vitro. J Neurophysiol 1997; 77: 378-85.

89 Trapp S, Ballanyi K. $\mathrm{K}_{\text {ATP }}$ channel mediation of anoxia-induced outward current in rat dorsal vagal neurons in vitro. J Physiol 1995; 487: 37-50.

90 Dunn-Meynell AA, Rawson NE, Levin BE. Distribution and phenotype of neurons containing the ATP-sensitive $\mathrm{K}^{+}$channel in rat brain. Brain Res 1998; 814: 41-54.

91 Liss B, Roeper J. A role for neuronal $\mathrm{K}_{\text {ATP }}$ channels in metabolic control of the seizure gate. Trends Pharmacol Sci 2001; 22: 599-601.

92 Sun HS, Feng ZP, Miki T, Seino S, French RJ. Enhanced neuronal damage after ischemic insults in mice lacking Kir6.2-containing ATPsensitive $\mathrm{K}^{+}$channels. J Neurophysiol 2006; 95: 2590-601.

93 Sun HS, Feng ZP, Barber PA, Buchan AM, French RJ. Kir6.2-containing ATP-sensitive potassium channels protect cortical neurons from ischemic/anoxic injury in vitro and in vivo. Neuroscience 2007; 144: 1509-15.

94 Miki T, Liss B, Minami K, Shiuchi T, Saraya A, Kashima Y, et al. ATPsensitive $\mathrm{K}^{+}$channels in the hypothalamus are essential for the maintenance of glucose homeostasis. Nat Neurosci 2001; 4: 507-12.

95 Yamada K, Ji JJ, Yuan H, Miki T, Sato S, Horimoto N, et al. Protective role of ATP-sensitive potassium channels in hypoxia-induced generalized seizure. Science 2001; 292: 1543-6.

96 Thomzig A, Laube G, Pruss H, Veh RW. Pore-forming subunits of $\mathrm{K}_{\text {ATP }}$ channels, Kir6.1 and Kir6.2, display prominent differences in regional and cellular distribution in the rat brain. J Comp Neurol 2005; 484: 313-30.

97 Mourre C, Ben AY, Bernardi H, Fosset M, Lazdunski M. Antidiabetic sulfonylureas: localization of binding sites in the brain and effects on the hyperpolarization induced by anoxia in hippocampal slices. Brain Res 1989; 486: 159-64.

98 Taborsky GJ Jr, Ahren B, Havel PJ. Autonomic mediation of glucagon secretion during hypoglycemia: implications for impaired alpha-cell responses in type 1 diabetes. Diabetes 1998; 47: 995-1005.

99 Karschin C, Ecke C, Ashcroft FM, Karschin A. Overlapping distribution of $\mathrm{K}_{\text {ATP }}$ channel-forming Kir6.2 subunit and the sulfonylurea receptor SUR1 in rodent brain. FEBS Lett 1997; 401: 59-64.

100 Pierrefiche O, Bischoff AM, Richter DW. ATP-sensitive $\mathrm{K}^{+}$channels are functional in expiratory neurones of normoxic cats. J Physiol 1996; 494: 399-409.

101 Allen TG, Brown DA. Modulation of the excitability of cholinergic basal forebrain neurones by $\mathrm{K}_{\text {ATP }}$ channels. J Physiol 2004; 554: 353-70.

102 Tanner GR, Lutas A, Martinez-Francois JR, Yellen G. Single $\mathrm{K}_{\text {ATP }}$ channel opening in response to action potential firing in mouse dentate granule neurons. J Neurosci 2011; 31: 8689-96.

103 Haller M, Mironov SL, Karschin A, Richter DW. Dynamic activation of K(ATP) channels in rhythmically active neurons. J Physiol 2001; 537 : 69-81.

104 Busija DW, Lacza Z, Rajapakse N, Shimizu K, Kis B, Bari F, et al. Targeting mitochondrial ATP-sensitive potassium channels - a novel approach to neuroprotection. Brain Res Rev 2004; 46: 282-94.

105 Zoga V, Kawano T, Liang MY, Bienengraeber M, Weihrauch D, McCallum $B$, et al. $K_{A T P}$ channel subunits in rat dorsal root ganglia: alterations by painful axotomy. Mol Pain 2010; 6: 6 .

106 Kawano T, Zoga V, Gemes G, McCallum JB, Wu HE, Pravdic D, et al. Suppressed $\mathrm{Ca}^{2+} / \mathrm{CaM} / \mathrm{CaMKII-dependent} \mathrm{K}_{\text {ATP }}$ channel activity in primary afferent neurons mediates hyperalgesia after axotomy. Proc Natl Acad Sci U S A 2009; 106: 8725-30.

107 Hernandez-Sanchez C, Basile AS, Fedorova I, Arima H, Stannard B,
Fernandez AM, et al. Mice transgenically overexpressing sulfonylurea receptor 1 in forebrain resist seizure induction and excitotoxic neuron death. Proc Natl Acad Sci U S A 2001; 98: 3549-54.

108 ladarola MJ, Gale K. Substantia nigra: site of anticonvulsant activity mediated by gamma-aminobutyric acid. Science 1982; 218 : $1237-$ 40.

109 Yamada K, Inagaki N. Neuroprotection by KATP channels. J Mol Cell Cardiol 2005; 38: 945-9.

110 Hicks GA, Hudson AL, Henderson G. Localization of high affinity $\left[{ }^{3} \mathrm{H}\right]$ glibenclamide binding sites within the substantia nigra zona reticulata of the rat brain. Neuroscience 1994; 61: 285-92.

111 Munoz A, Nakazaki M, Goodman JC, Barrios R, Onetti CG, Bryan J, et al. Ischemic preconditioning in the hippocampus of a knockout mouse lacking SUR1-based $K_{\text {ATP }}$ channels. Stroke 2003; 34: 16470.

112 Benarroch EE. Potassium channels: brief overview and implications in epilepsy. Neurology 2009; 72: 664-9.

113 Gloyn AL, Pearson ER, Antcliff JF, Proks P, Bruining GJ, Slingerland AS, et al. Activating mutations in the gene encoding the ATP-sensitive potassium-channel subunit Kir6.2 and permanent neonatal diabetes. N Engl J Med 2004; 350: 1838-49.

114 Ashcroft FM. Adenosine 5'-triphosphate-sensitive potassium channels. Annu Rev Neurosci 1988; 11: 97-118.

115 Heurteaux C, Bertaina V, Widmann C, Lazdunski M. $\mathrm{K}^{+}$channel openers prevent global ischemia-induced expression of c-fos, c-jun, heat shock protein, and amyloid beta-protein precursor genes and neuronal death in rat hippocampus. Proc Natl Acad Sci U S A 1993; 90: 9431-5.

116 Asemu G, Papousek F, Ostadal B, Kolar F. Adaptation to high altitude hypoxia protects the rat heart against ischemia-induced arrhythmias. Involvement of mitochondrial K(ATP) channel. J Mol Cell Cardiol 1999; 31: 1821-31.

117 Testai L, Rapposelli S, Calderone V. Cardiac ATP-sensitive potassium channels: a potential target for an anti-ischaemic pharmacological strategy. Cardiovasc Hematol Agents Med Chem 2007; 5: 79-90.

118 Kim KO, Choe G, Chung SH, Kim CS. Delayed pharmacological preconditioning effect of mitochondrial ATP-sensitive potassium channel opener on neurologic injury in a rabbit model of spinal cord ischemia. Acta Anaesthesiol Scand 2008; 52: 236-42.

119 Mayanagi K, Gaspar T, Katakam PV, Busija DW. Systemic administration of diazoxide induces delayed preconditioning against transient focal cerebral ischemia in rats. Brain Res 2007; 1168: 106-11.

120 Shimizu K, Lacza Z, Rajapakse N, Horiguchi T, Snipes J, Busija DW. MitoK(ATP) opener, diazoxide, reduces neuronal damage after middle cerebral artery occlusion in the rat. Am J Physiol Heart Circ Physiol 2002; 283: H1005-11.

121 Mayanagi K, Gaspar T, Katakam PV, Kis B, Busija DW. The mitochondrial $K_{\text {ATP }}$ channel opener BMS-191095 reduces neuronal damage after transient focal cerebral ischemia in rats. J Cereb Blood Flow Metab 2007; 27: 348-55.

122 Liu D, Lu C, Wan R, Auyeung WW, Mattson MP. Activation of mitochondrial ATP-dependent potassium channels protects neurons against ischemia-induced death by a mechanism involving suppression of Bax translocation and cytochrome c release. J Cereb Blood Flow Metab 2002; 22: 431-43.

123 Liu D, Slevin JR, Lu C, Chan SL, Hansson M, Elmer E, et al. Involvement of mitochondrial $\mathrm{K}^{+}$release and cellular efflux in ischemic and apoptotic neuronal death. J Neurochem 2003; 86: 966-79.

124 Bantel C, Maze M, Trapp S. Neuronal preconditioning by inhalational anesthetics: evidence for the role of plasmalemmal adenosine triphosphate-sensitive potassium channels. Anesthesiology 2009; 
110: 986-95.

125 Gross GJ , Fryer RM. Sarcolemmal versus mitochondrial ATP-sensitive $\mathrm{K}^{+}$channels and myocardial preconditioning. Circ Res 1999; 84: 973-9.

126 Blondeau N, Plamondon H, Richelme C, Heurteaux C, Lazdunski M. $\mathrm{K}_{\text {ATP }}$ channel openers, adenosine agonists and epileptic preconditioning are stress signals inducing hippocampal neuroprotection. Neuroscience 2000; 100: 465-74.

127 Lipton P. Ischemic cell death in brain neurons. Physiol Rev 1999; 79: 1431-568.

128 Johansen FF. Interneurons in rat hippocampus after cerebral ischemia. Morphometric, functional, and therapeutic investigations. Acta Neurol Scand Suppl 1993; 150: 1-32.

129 Yamamoto S, Tanaka E, Higashi H. Mediation by intracellular calcium-dependent signals of hypoxic hyperpolarization in rat hippocam- pal CA1 neurons in vitro. J Neurophysiol 1997; 77: 386-92.

130 Garcia de AS, Franke H, Pissarek M, Nieber K, Illes P. Neuroprotection by ATP-dependent potassium channels in rat neocortical brain slices during hypoxia. Neurosci Lett 1999; 273: 13-6.

131 Heron-Milhavet L, Xue-Jun Y, Vannucci SJ, Wood TL, Willing LB, Stannard $\mathrm{B}$, et al. Protection against hypoxic-ischemic injury in transgenic mice overexpressing Kir6.2 channel pore in forebrain. Mol Cell Neurosci 2004; 25: 585-93.

132 Simard JM, Chen M, Tarasov KV, Bhatta S, Ivanova S, Melnitchenko L, et al. Newly expressed SUR1-regulated NC(Ca-ATP) channel mediates cerebral edema after ischemic stroke. Nat Med 2006; 12 : 433-40.

133 Ortega FJ, Gimeno-Bayon J, Espinosa-Parrilla JF, Carrasco JL, Batlle $\mathrm{M}$, Pugliese M, et al. ATP-dependent potassium channel blockade strengthens microglial neuroprotection after hypoxia-ischemia in rats. Exp Neurol 2012; 235: 282-96. 